\title{
Zika virus in Brazil and the danger of infestation by Aedes (Stegomyia) mosquitoes
}

\author{
Carlos Brisola Marcondes ${ }^{[1]}$ and Maria de Fátima Freire de Melo Ximenes ${ }^{[2]}$
}

[1]. Departamento de Microbiologia, Imunologia e Parasitologia, Centro de Ciências Biológicas, Universidade Federal de Santa Catarina, Florianópolis, Santa Catarina, Brasil. [2]. Departamento de Microbiologia e Parasitologia, Centro de Biociências, Universidade Federal do Rio Grande do Norte, Natal, Rio Grande do Norte, Brasil.

\begin{abstract}
Zika virus, already widely distributed in Africa and Asia, was recently reported in two Northeastern Brazilian: State of Bahia and State of Rio Grande do Norte, and one Southeastern: State of São Paulo. This finding adds a potentially noxious virus to a list of several other viruses that are widely transmitted by Aedes (Stegomyia) aegypti and Aedes (Stegomyia) albopictus in Brazil. The pathology and epidemiology, including the distribution and vectors associated with Zika virus, are reviewed. This review is focused on viruses transmitted by Aedes (Stegomyia) mosquitoes, including dengue, Chikungunya, Zika, Mayaro, and yellow fever virus, to emphasize the risks of occurrence for these arboviruses in Brazil and neighboring countries. Other species of Aedes (Stegomyia) are discussed, emphasizing their involvement in arbovirus transmission and the possibility of adaptation to environments modified by human activities and introduction in Brazil.
\end{abstract}

Keywords: Aedes aegypti. Aedes albopictus. Arbovirus. Stegomyia. Culicidae.

\section{INTRODUCTION}

Ten arboviruses have recently been reviewed as important emergent disease agents in Brazil ${ }^{(1)}$, of which Aedes aegypti can transmit dengue virus (DENV), yellow fever virus (YFV), Chikungunya virus $(\mathrm{CHIKV})^{(2)}$, Venezuelan equine encephalitis virus $(\mathrm{VEEV})^{(3)}$, and Mayaro virus (MAYV) ${ }^{(2)(4)}$. In addition, Aedes albopictus can transmit several arboviruses ${ }^{(5)}$, as detailed below.

The DENV, MAYV, YFV, Rocio, Saint Louis, and Oroupoche viruses are responsible for over $95 \%$ of cases of arbovirus infection in Brazil; DENV is the most prevalent, causing separate epidemics by dengue virus serotype 1 (DENV-1), dengue virus serotype 2 (DENV-2), dengue virus serotype 3 (DENV3 ), and dengue virus serotype 4 (DENV-4), in the country ${ }^{(6)}$. MAYV was recently identified in sera of patients from Mato Grosso, Brazil, who had been previously diagnosed with dengue fever. MAYV was detected in humans of both sexes between 14 and 62 years of age, most of whom presented with fever, nausea, vomit, myalgia, arthralgia, and ocular and abdominal $\operatorname{pain}^{(7)}$.

Zika virus (ZIKV), previously reported in Africa and $\mathrm{Asia}^{(8)}$ and now in Brazil( ${ }^{(9)(10)(11)}$, causes dengue fever-like symptoms and is transmitted by Aedes (Stegomyia) mosquitoes, emphasizing the need for a review of the vectorial role of these mosquitoes and on diagnosis and disease control.

Corresponding author: Dr. Carlos Brisola Marcondes.

e-mail: cbrisolamarcondes@gmail.com

Received 6 July 2015

Accepted 14 September 2015
The division of Aedes into Stegomyia and other genera ${ }^{(12)}$ has been accepted ${ }^{(13)}$. However, the more traditional and comprehensive Aedes definition, commonly used by public health workers, is utilized here; special abbreviations for genera and subgenera ${ }^{(14)}$ are also utilized.

\section{DENGUE AND CHIKUNGUNYA}

The spread of DENV into the Americas from 1995 to 2010 resulted in greater incidences of infection in Brazil, compared to that found in Ecuador, Paraguay, Peru, Costa Rica, Bolivia, Argentina, Mexico, and Nicaragua. A total of 2,756,622 cases of DENV were reported in Brazil between 2002 and 2007, being $98.5 \%$ of total in South Cone ${ }^{(15)}$. The available data demonstrate the dissemination of Ae. aegypti, the circulation of 4 DENV serotypes, and difficulty in eradicating or controlling the mosquito.

Coincident with a water-supply crisis in São Paulo, which caused the general population to store water using improvised methods, the numbers of DENV cases (and related deaths) markedly increased in this state. With sequential infections with the 4 serotypes, DENV can cause symptoms ranging from mild influenza-like symptoms to hemorrhagic fever and death. The virus is usually transmitted by Ae. aegypti, but can also be transmitted by Ae. albopictus.

The habitat of Aedes aegypti influences the potential areas of YFV and DENV transmission. Dengue fever occurs predominantly in urban and densely populated areas, where it is transmitted by Ae. aegypti, a mosquito also occasionally found in rural areas. A precarious water supply may result in the 
maintenance and transportation of water containers containing mosquito eggs, and patients infected by DENV and YFV may then migrate from urban and sylvatic areas, promoting viral dissemination. Although DENV control has been promoted in Brazil, its easy transmission, due to widespread dispersion of Ae. aegypti and its good adaptation to urban areas, has made it very difficult. Garbage dispersed in urban areas is the most important breeding site for this mosquito ${ }^{(16)}$.

Migration from rural to urban areas and living under a precarious infrastructure, including the water supply, has contributed to mosquito breeding. In the northeast region of Brazil, over $75 \%$ of breeding sites arise due to precarious water storage, while in the southeast region most breeding sites occur in other domiciliary vessels (jars, plant pots, and roof gutters) ${ }^{(16)}$.

In equatorial West Africa, CHIKV has a zoonotic cycle, involving mostly non-human primates and aedine mosquitoes. Although viral antigens have been found in birds and rodents, these animals do not seem to serve an important role in the CHIKV replication cycle, as the principal vectors rarely feed on them ${ }^{(17)}$. Between epidemic periods, CHIKV is maintained in Africa among Aedes (Stegomyia) africanus, Aedes (Stg.) luteocephalus, Aedes (Stg.) furcifer, and sylvatic primates. Urban outbreaks in east Africa and Asia involve Ae. aegypti, Ae. albopictus, and humans ${ }^{(18)}$.

Recently, CHIKV has been reported from the United States (Florida), El Salvador, Costa Rica, Panama, Caribbean islands, Venezuela, and the Guyanas ${ }^{(19)}$, and caused a great number of infections in the Brazilian States of Amapá, Bahia, and Minas Gerais in 2014 ${ }^{(2)}$. Because the lineage of CHIKV isolated from the Americas is different from that of the Indian Ocean Lineage (IOL), which is adapted to Ae. albopictus, the possibility of transmission by the latter lineage was previously considered remote ${ }^{(20)}$. However, tests of 22 populations of Ae. aegypti and 13 of Ae. albopictus from Brazil and 9 other countries showed a high susceptibility and capacity for transmission of both lineages. In fact, $96.7 \%$ of an Ae. albopictus subpopulation from Rio de Janeiro were capable of transmitting CHIKV, and 1 subpopulation from this city transmitted the virus as soon as 2 days after infection ${ }^{(21)}$.

Large international competitions such as the World Soccer Cup in 2014 and the Olympic games in 2016 may promote the introduction of new viruses into Brazil. The occurrence of CHIKV indicated the possibility of introducing pathogens from regions with different climates, if adequate vectors are available.

Molecular methods used in Korea permitted the diagnosis of CHIKV infection in patients originally suspected as being infected by DENV ${ }^{(22)}$. Thus, these diseases will need to be adequately diagnosed in Brazil, where both have been reported.

\section{ZIKA VIRUS}

Zika virus is a flavivirus, originally isolated in 1947 from a rhesus monkey utilized as bait for a study of YFV in the Zika forest, near Kampala, Uganda ${ }^{(23)}$. It has been isolated in several African countries (Uganda, Tanzania, Egypt, Central African Republic, Sierra Leone, and Gabon), Asian countries
(India, Malaysia, the Philippines, Thailand, Vietnam and Indonesia), and in Micronesia( ${ }^{(8)(24)}$.

Diagnosis of ZIKV infection in Brazilian patients has been done by reverse transcription-polymerase chain reactions ${ }^{(11)}$. A generic test (the Generic reverse transcription (RT)-nestedpolymerase chain reaction (PCR) test for flaviviruses), followed by sequencing for specific viruses was proposed ${ }^{(25)}$, and specific diagnosis of ZIKV in field-collected mosquitoes can be accomplished by quantitative real-time $\mathrm{PCR}^{(26)}$.

Infection by ZIKV causes symptoms similar to those of DENV (malaise, chills, fever, headache, muscle pain, arthralgia, and periorbital pain). Similarly, no cases of permanent damage to articulations (like those caused by CHIKV) and no deaths have been observed. However, during an investigation of yellow fever in Eastern Nigeria, ZIKV was isolated from 2 icteric patients not infected by malaria or $\mathrm{YFV}^{(27)}$. In mice, ZIKV is highly neurotropic; the virus was not isolated from tissues other than brain, and pathology showed neuronal degeneration, cellular infiltration, and softening in the brain in infected, young mice. Infected Rhesus monkeys presented with transient pyrexia ${ }^{(23)}$. Seven patients from Indonesia that were serologically reactive to ZIKV showed high fever, malaise, chills, anorexia, vomiting, diarrhea, stomach aches, dizziness, leg pain, lymphadenopathy and, more worrying, hypotension ${ }^{(28)}$.

After the description of a ZIKV-associated case of GuillainBarré syndrome (tetraparesis predominantly in the lower limbs, paresthesia of the extremities, diffuse myalgia, a bilateral but asymmetric facial palsy, with abolition of deep tendon reflexes) in French Polynesia ${ }^{(29)}$, another 40 cases of this syndrome were described in the same country ${ }^{(30)}$. Therefore, the qualification of ZIKV as a mild cousin of dengue ${ }^{(31)}$ may not be adequate, due to the possibility of more serious disease symptoms, especially in non-immunocompetent patients.

In Italy, 2 cases of ZIKV infection in individuals arriving from French Polynesia were diagnosed, who presented with low-grade fever, malaise, conjunctivitis, myalgia, arthralgia, ankle edema, and axillary and inguinal lymphadenopathy. One patient, returning to Italy from a 12-day stay in Salvador, Bahia, in March 2015, showed leukopenia, with monocytosis and thrombocytopenia ${ }^{(32)}$.

Since February 2015, the Secretary of Health Vigilance [Secretaria de Vigilância em Saúde (SVS)] has monitored all patients presenting with exanthematic diseases. All individuals suspected of having ZIKV infection reported by the State secretaries of Bahia, Sergipe, Paraíba, Rio Grande do Norte, and Maranhão have presented with self-limiting symptoms, mostly exanthema, pruritus, occasional fevers, headaches, arthralgia, and muscular pain, and clinical intervention was not required. Most patients were 20 to 40 years old, but their ages varied from 4 months to 98 years old. Eight patients from the Brazilian State of Rio Grande do Norte were diagnosed with ZIKV infection by the Laboratory of Molecular Virology of Carlos Chagas Institute of the Oswaldo Cruz Foundation [Laboratório de Virologia Molecular (LVM) do Instituto Carlos Chagas (ICC) da Fundação Oswaldo Cruz (FIOCRUZ) State of Paraná], utilizing RT-PCR, confirmed by viral genome sequencing, 
which indicated that the strains were Asiatic ${ }^{11}$. These findings confirmed ZIKV circulation in Brazil and indicated the need for epidemiological vigilance. ZIKV was recently reported in 7 Brazilian States (the above mentioned Cities, as well as Pará and São Paulo), and a case of transmission by blood transfusion was reported $^{(33)}$. The isolation of ZIKV from 3\% of blood donors in French Polynesia had already raised the potential for this form of transmission ${ }^{(34)}$.

The recent rise in microcephaly incidences in several northeastern states, with 1,248 cases reported in 2015 up through November $30^{\text {th }(35)}$, has been strongly suspected of being associated with ZIKV, with the virus being found in the amniotic fluid of 2 pregnant women whose fetuses presented a reduction in the circumference of the head ${ }^{(36)}$. This serious effect of ZIKV infection on fetuses, not previously reported, is unsurprising considering the perinatal transmission reported for 2 women from French Polynesia( $^{(37)}$ and the strong neurotropism of the virus ${ }^{(23)}$.

Zika virus was probably introduced in Brazil during the World Soccer Cup, in 2014, when many tourists visited the Natal and other Brazilian capitals, possibly contributing to the infection of Aedes (Stegomyia) mosquitoes. Because dengue fever occurred in several cities where the games were played, tourists could also have acquired the viruses, possibly carrying them when going back to their respective homes.

Rapid travel and commerce link urban centers allowing for the rapid movement of both vector mosquitoes and infected humans. Commonly, humans have facilitated the widespread establishment of the vectors, with enhanced viral dissemination following shortly thereafter. Established vectors can rapidly move within cars, trucks, planes, or other forms are transportation, allowing a hop scotch type of viral transmission, resulting in rapidly and randomly spread outbreaks. From 2011 to 2014, concomitant infections with DENV, CHIKV, and ZIKV (Asian strain) were observed in the Pacific region ${ }^{(38)}$, as could be expected given that these viruses use the same vectors (Ae. aegypti and Ae. albopictus).

Zika virus has been isolated from Aedes aegypti, Aedes africanus $^{(23)(39)}$, Aedes luteocephalus, Aedes (Fredwardsius) vittatus, Aedes (Stg.) apicoargenteus, Aedes (Diceromyia) furcifer in a village in Senegal ${ }^{(40)}$, and Aedes albopictus in Gabon ${ }^{(41)}$, representing the first report of ZIKV transmission by this mosquito in urban areas. ZIKV was also isolated from 31 pools of several species of aedine mosquitoes; from Mansonia uniformis, Culex perfuscus, and Anopheles coustani (one pool each); and Aedes vittatus and Aedes furcifer ${ }^{(40)}$; their vectorial roles need to be clarified. Transmission by Aedes aegypti was observed ${ }^{(42)}$. Aedes (Stg.) hensilli mosquitoes were not found to be infected by ZIKV in Yap Island, Micronesia, where an outbreak occurred in $2007^{(24)}$. However, its predominance in the collections and high susceptibility to experimental infection made it very suspect as a vector of the virus ${ }^{(43)}$. ZIKV was isolated from semen in a patient from French Polynesia ${ }^{(4)}$, and non-vector borne, probably sexual, transmission was observed in humans in USA ${ }^{(45)}$.

Yellos fever virus was introduced from Africa to the Americas and afterwards adapted to local sylvatic vectors ${ }^{(46)}$. ZIKV and other arboviruses currently transmitted by urban mosquitoes can also adapt to Neotropical mosquitoes and primates, jeopardizing any future control.

\section{VECTORIAL ROLE OF AEDES (STEGOMYIA) MOSQUITOES}

Owing to their wide distribution in the American and other continents and their involvement as vectors of several arboviruses, Aedes (Stegomyia) mosquitoes are of great medical importance. In Latin America, Ae. aegypti and Ae. albopictus are widely distributed and very numerous in most small and large cities. As in other continents, rapid human population growth and uncontrolled urbanization, leading to slums with inadequate infrastructure and piped water, have made it very difficult to reduce the populations of Ae. aegypti mosquitoes to safe levels.

Zika virus is only 1 additional virus to the list of arbovirus transmitted by the above species of this subgenus, whose vectorial role is briefly discussed below.

The Stegomyia subgenus includes 128 species $^{(47)}$, mostly from Africa, Asia, and Oceania. Some of them have been found in manmade containers ${ }^{(48)}$ and/or have adapted to urban conditions. In recent years, these species have been introduced in new areas, like the Americas (Ae. aegypti and Ae. albopictus) and Europe (Aedes albopictus), being implicated as vectors of several arboviruses. The most important species are analyzed below.

Breeding of the sylvatic forms of Aedes aegypti such as Aedes aegypti formosus in Africa occurs mostly in riverbeds, tree holes, and rock pools, but these aedine mosquitoes have become well adapted to urban environments. Females typically oviposit and immature forms can develop in clean water or water containing a moderate amount of organic matter in various types of vessels, including barrels, tires, plant pots, roof gutters, and more rarely in leaf axils and bamboo stumps ${ }^{(48)}$, stream pools, tree holes, nuts, and coconut shells ${ }^{(49)}$. Aedes aegypti appears to rarely invade sylvatic environments ${ }^{(50)}$, but it has occasionally been identified in 2 localities in Rio Grande do Norte, namely (Floresta Nacional (FLONA) - Nísia Floresta, Natal), constituted by Atlantic forest, and Ecological Station Seridó, an area with xerophilous vegetation (caatinga) (Maria de Fátima M Ximenes, unpublished observation).

Aedes aegypti is the primary vector of DENV and YFV, and its susceptibility to infection is genetically influenced ${ }^{(51)}$. This mosquito has also been implicated as a vector of CHIKV, and if Mayaro virus becomes adapted to urban environments, Ae. aegypti may also serve as a vector for this virus ${ }^{(2)}$. It has occasionally been found infected with West Nile virus, recently reported in Brazil ${ }^{(52)}$, whose major vectors are Culex mosquitoes ${ }^{(53)}$. Aedes aegypti has served as the urban vector of YFV, although YFV has not been transmitted in urban settings in Brazil since 1942. However, because urban YFV infections were recently observed in Bolivia ${ }^{(54)}$, they can also potentially occur in Brazil. The basic reproduction number $\left(\mathrm{R}_{0}\right)$ of Ae. aegypti for urban YFV transmission was $43 \%$ lower than that for the initial phase of DENV epidemics, and several cities in the State of São Paulo with $\mathrm{R}_{0} \mathrm{~s}>1$ for DENV are high-risk areas for $\mathrm{YFV}^{(55)}$. The $\mathrm{R}_{0}$ for CHIKV is $64.4 \%$ of that for $\mathrm{DENV}^{(56)}$. 
Aedes albopictus was previously distributed only in Asia, but was transported to other continents via commerce, and it is now considered an important invasive mosquito ${ }^{(57)}$. In Brazil, Ae. albopictus was present in 59\% of municipalities in $2014^{(58)}$ and in 24 of 27 states $^{(59)}$. It is adapted to both urban and sylvatic habitats, including bromeliads ${ }^{(60)}$, tree holes (also with Ae. aegypti and Ae. vittatus) $)^{(61)}$, and perforated bamboo internodes ${ }^{(62)}$, and is a suspected link for YFV between preserved and modified environments in the south and southeast regions of Brazil ${ }^{(63)}$. This species is both endophagic and exophagic, feeding on a wide range of hosts, in comparison to Ae. aegypti that feeds mostly indoors on humans.

Experimentally, Aedes albopictus may transmit 22 different arboviruses ${ }^{(64)}$. As a good experimental vector of $\mathrm{YFV}^{(65)}$, Ae. albopictus could potentially transmit YFV if an overlap of their distribution occurs ${ }^{(63)}$. Haemagogus janthinomys, Haemagogus leucocelaenus, and Ae. serratus were found to be infected with YFV in Brazil(66)(67). In the Federal District, Ae. albopictus was found in São Sebastião, near the locality where YFV was isolated ${ }^{(66)}$, while the northwest region of Rio Grande do Sul currently harbors several cases of DENV infection ${ }^{(68)}$, with the affected areas certainly being infested by Ae. aegypti and possibly by Ae. albopictus. In central Africa, the presence of Ae. albopictus was more frequent than Ae. aegypti in suburban environments, and in Libreville (Gabon), CHIKV and DENV were isolated only from Ae. albopictus ${ }^{(69)}$. In Brazil, Ae. albopictus does not seem to be an important vector of $\mathrm{DENV}^{(70)}$, but its role as vector of CHIKV and other arboviruses in Brazil needs to be more thoroughly studied.

Aedes africanus, abundant and found infected by ZIKV in the Zika forest, was initially suspected as the primary vector for this virus ${ }^{(23)}$. ZIKV has been repeatedly isolated from Aedes africanus in the Zika forest, and only pools from this species (among 115 pools representing several species) were positive ${ }^{(39)}$. CHIKV also was isolated from Ae. africanus mosquitoes and from collectors in this forest, and vertical distribution at night and during the day was different ${ }^{(39)}$, emphasizing the role of this Aedes (Stegomyia) mosquito in the zoonotic transmission of both arboviruses.

The introduction of Aedine species of 10 genera (all included here in genus Aedes) was reviewed ${ }^{(71)}$, and only Aedes aegypti and Aedes albopictus of Stegomyia were found to be dispersed from their original areas. Other species of this subgenus are normally restricted to the Pacific and Indian oceans or African localities. However, although improbable, it is possible that species such as Aedes simpsoni, which is associated with plant axils $^{(72)}$ and artificial containers ${ }^{(73)}$ in Africa and whose role in YFV replication was reproduced by Aedes albopictus, Aedes gardnerii, and Aedes desmotes from bamboos in Philippines ${ }^{(74)}$, could invade and colonize Brazil. Aedes flavopictus and Aedes scutellaris are also good candidates for invading the American continents, and the last species was found in a California port facility just after World War II and quickly eliminated (Bruce Harrison, personal communication). Several species of the Scutellaris group of Stegomyia, which includes Aedes hensilli and Aedes albopictus, should be considered as potential vectors of ZIKV in Southeast Asia and Oceania ${ }^{(43)}$. The finding of Wyeomyia mitchellii, a sylvatic bromeliad-associated American species, in Hawaii ${ }^{(75)}$ and French Polynesia ${ }^{(76)}$ indicates the possibility of invasion of new regions by mosquitoes not associated to human modified habitats.

Aedes koreicus and Aedes japonicus are 2 examples of invaders of potential health importance. Well adapted to rock pools and other containers ${ }^{(77)(78)(79)(80)}$, the former species is now widely distributed in Europe ${ }^{(77)}$, and the latter is distributed in the USA and Europe ${ }^{(78)(79)(80)}$. The ecological and health implications of 5 invaders of Europe (Aedes aegypti, Aedes albopictus, Aedes japonicus, Aedes koreicus and Aedes atropalpus) were thoroughly reviewed, with the first 2 species already involved in disease transmission in Europe and Aedes albopictus and Aedes japonicus already showing widespread distribution ${ }^{(80)}$.

Controlling the dissemination of vector insects to prevent the transmission of pathogens requires an understanding of several aspects of their bioecologies. Studies of Ae. japonicus have demonstrated that the interaction of this invasive species with other local species influences its population dynamics and the transmission of pathogens. Aedes japonicus coexists with other immature mosquito forms and, although not yet completely cleared, at least 2 native species (Aedes triseriatus and Aedes atropalpus) are being dislodged. Interactions with Ae. albopictus also can limit its area of dispersion. Stress in larval environments resulting from competition for food and abiotic factors can enhance the virus transmission efficiency of adults emerging from such habitats. Aedes albopictus transmits Japanese encephalitis virus and has shown vectorial competence for CHIKV and DENV, being dispersed in Europe and the United States.

The observation of sexual interference of Aedes albopictus male mosquitoes with females of Ae. aegypti( ${ }^{(81)}$, referred to as satyrism $^{(82)}$, emphasizes the need for additional studies on the ecology of Aedes (Stegomyia) mosquitoes and their mutual interactions.

These data illustrate the dangers of invasive species and the needs for vigilance and a good comprehension of mosquito biology and their interactions with other species. While the usual vectors of CHIKV and DENV are known, the possibility that other species may become established as efficient transmitters of arboviruses cannot be discounted. Like Ae. aegypti, Ae. japonicus utilizes several types of water containers, can be transported in tires, is anthropophilic and peridomestic ${ }^{(83)}$.

The efficient adaptation of Aedes aegypti to urban areas makes their control difficult. Only the improvement of sanitation and municipal infrastructure of cities, an almost impossible task in areas with progressive urbanization, budgetary restrictions and low collaboration of populations, can lead to effective control. Aedes albopictus is less adapted to domestic environments than is Ae. aegypti, but is widely distributed in peridomestic habitats within cities. For example, it is easy to collect eggs laid by Aedes albopictus mosquitoes in small ovitraps in the neighborhood of the first author department, located near the busiest avenue of Florianópolis. In the last 10 years, ovitraps installed near State Park Dunas de Natal, the second biggest urban park in Brazil, 
have been used to obtain eggs of Ae. albopictus, which were similarly obtained near the Federal University of Rio Grande do Norte buildings.

Studies on the feeding preferences of Aedes albopictus have indicated a preference for mammals in suburban areas of the USA ${ }^{(84)}$. Eighty-three percent of female Ae. albopictus mosquitoes in suburban areas of Singapore had fed on humans; but some were reactive to shrews, swine, dogs, cats, turtles, and other hosts in rural settings. In urban areas, all positive blood meals were from humans ${ }^{(85)}$.

The wide distribution of DENV and the growing menace of CHIKV, ZIKV, and other viruses in Brazil constitute a serious problem that needs to be addressed. Although some candidate vaccines for DENV will soon be launched in Brazil, vaccines for the other 2 viruses have not been developed.

Thus, at present, the only possible intervention for controlling these arboviruses is an extreme reduction in the populations of Stegomyia mosquitoes. Such intervention is less difficult for $A e$. aegypti, which rarely migrates to forest areas, in contrast to $A e$. albopictus $^{(84)}$. Alternative tools for controlling mosquito-borne diseases, like the utilization of Wolbachia bacteria ${ }^{(86)}$ and of sterile males associated to insecticides ${ }^{(87)}$ must be investigated further, but the careful reduction of potential breeding places is probably the most important method for their control.

\section{ACKNOWLEDGMENTS}

We thank William Reisen for critically reading this manuscript and for providing helpful suggestions. Bruce Harrison and Ralph Harbach provided key information regarding potential invading species. Luis Adrián Diaz shared comments pertaining to the diagnosis of ZIKV and other flaviviruses.

\section{CONFLICT OF INTEREST}

The authors declare that there is no conflict of interest.

\section{REFERENCES}

1. Figueiredo LT. Emergent arboviruses in Brazil. Rev Soc Bras Med Trop 2007; 40:224-229.

2. Figueiredo ML, Figueiredo LT. Emerging alphaviruses in the Americas: Chikungunya and Mayaro. Rev Soc Bras Med Trop 2014; 47:677-683.

3. Ortiz DI, Kang W, Weaver SC. Susceptibility of Ae. aegypti (Diptera: Culicidae) to infection with epidemic (subtype IC) and enzootic (subtypes ID, IIIC, IIID) Venezuelan equine encephalitis complex alphaviruses. J Med Entomol 2008; 45:1117-1125.

4. Aitken TH, Anderson CR. Virus transmission studies with Trinidadian mosquitoes II. Further observations. Am J Trop Med Hyg 1959; 8:4145 .

5. Alencar CHM, Albuquerque LM, Aquino TMF, Soares CB, Ramos Júnior AN, Lima JWO, et al. Potencialidades do Aedes albopictus como vetor de arboviroses no Brasil: um desafio para a atenção primária. Rev APS 2008; 11:459-467.
6. Vasconcelos PFC, Travassos da Rosa APA, Pinheiro FP, Shope RE, Travassos da Rosa JFS, Rodrigues SG, et al. Arboviruses pathogenic for man in Brazil. In: Travassos da Rosa APA, Vasconcelos PFC, Travassos da Rosa JFS, editors. An overview of arbovirology in Brazil and neighbouring countries. Belém: Instituto Evandro Chagas; 1998. p. 72-99.

7. Vieira CJ, Silva DJ, Barreto ES, Siqueira CE, Colombo TE, Ozanic K, et al. Detection of Mayaro virus infections during a dengue outbreak in Mato Grosso, Brazil. Acta Trop 2015; 147:12-16.

8. Hayes EB. Zika virus outside Africa. Emerg Infect Dis 2009; 15:13471350.

9. Portal da Saúde - Ministério da Saúde (Internet). Confirmação do Zika Vírus no Brasil. Brasília: Ministério da Saúde; 2015. (Accessed Dec 7, 2015). Available at http://portalsaude.saude.gov.br/index.php/oministerio/principal/secretarias/svs/noticias-svs/17702-confirmacaodo-zika-virus-no-brasil

10. Empresa Brasil de Comunicação S/A - EBC Agência Brasil. Primeiro caso de zika virus é confirmado no Estado de São Paulo. EBC Agência Brasil; 2015. (Accessed 2015 Dec 7th). Available at http://agenciabrasil. ebc.com.br/geral/noticia/2015-05/primeiro-caso-de-zika-virus-econfirmado-em-sao-paulo

11. Zanluca C, Melo VCA, Mosimann ALP, Santos GIV, Santos CND, Luz K. First report of autochthonous transmission of Zika virus in Brazil. Mem Inst Oswaldo Cruz 2015; 110:569-572.

12. Reinert JF, Harbach RE, Kitching IJ. Phylogeny and classification of Aedini (Diptera: Culicidae). Zool J Linn Soc 2009; 157:700-794.

13. Marcondes CB. Taxonomic changes: disprove or accept them. Trends Parasitol 2007; 23:302-303.

14. Reinert JF. Mosquito generic and subgeneric abbreviations (Dipter: Culicidae). Mosquito Syst 1975; 7:105-110.

15. World Health Organization (WHO). Dengue: guidelines for diagnosis, treatment, prevention and control. WHO-TDR. 2009. 147 p.

16. Boechat B. Ministério da Saúde divulga principais criadouros de dengue por região. Portal Extra Globo; 2015. (Accessed 2015 Dec $7^{\text {th }}$ ). Available at: http://extra.globo.com/noticias/saude-e-ciencia/dengue/ ministerio-da-saude-divulga-principais-criadouros-de-dengue-porregiao-11921245.html

17. Faraji A, Egizi A, Fonseca DM, Unlu I, Crepeau T, Healy SP, et al. Comparative host feeding patterns of the Asian tiger mosquito, Aedes albopictus, in urban and suburban Northeastern USA and implications for disease transmission. PLoS Negl Trop Dis 2014; 8:e3037.

18. Chevillon C, Briant L, Renaud F, Devaux C. The chikungunya threat: an ecological and evolutionary perspective. Trends Microbiol 2008; 16:80-88.

19. Staples JE, Fischer M. Chikungunya virus in the Americas - what a vectorborne pathogen can do. N Engl J Med 2014; 371:887-889.

20. Weaver SC. Arrival of Chikungunya virus in the New World: prospects for spread and impact on public health. PLOS Negl Trop Dis 2014; 8:e2921.

21. Vega-Rúa A, Zouache K, Girod R, Failloux AB, Lourenço-deOliveira R. High level of vector competence of Aedes aegypti and Aedes albopictus from ten American countries as a crucial factor in the spread of Chikungunya virus. J Virol 2014; 88:6294-6306.

22. Cha GW, Cho JE, Lee EJ, Ju YR, Han MG, Park C, et al. Travelassociated Chikungunya cases in South Korea during 2009-2010. Osong Public Health Res Perspect 2013; 4:170-175.

23. Dick GW, Kitchen SF, Haddow AJ. Zika virus. I. Isolations and serological specificity. Trans R Soc Trop Med Hyg 1952; 46:509-520.

24. Lanciotti RS, Kosoy OL, Laven JJ, Velez JO, Lambert AJ, Johnson AJ, et al. Genetic and serologic properties of Zika virus associated with an epidemic, Yap State, Micronesia, 2007. Emerg Infect Dis 2008; 14:1232-1239. 
25. Sánchez-Seco MP, Rosario D, Domingo C, Hernández L, Valdés K, Guzmán MG, et al. Generic RT-nested-PCR for detection of flaviviruses using degenerated primers and internal control followed by sequencing for specific identification. J Virol Methods 2005; 126:101-109.

26. Faye O, Faye O, Diallo D, Diallo M, Weidmann M, Sall AA. Quantitative real-time PCR detection of Zika virus and evaluation with field-caught mosquitoes. Virol J 2013; 10:311.

27. Macnamara FN. Zika virus: a report on three cases of human infection during an epidemic of jaundice in Nigeria. Trans R Soc Trop Med Hyg 1954; 48:139-145.

28. Olson JG, Ksiazek TG, Suhadiman, Triwibowo. Zika virus, a cause of fever in Central Java, Indonesia. Trans R Soc Trop Med Hyg 1981; 75:389-393.

29. Oehler E, Watrin L, Larre P, Lepark-Goffart I, Lastère S, Valour F, et al. Zika virus infection complicated by Guillain-Barré syndrome - case report, French Polynesia, December 2013. Euro Surveill 2014; 19:pii:20720.

30. Ioos S, Mallet HP, Goffart IL, Gauthier V, Cardoso T, Herida M. Current Zika virus epidemiology and recent epidemics. Med Mal Infect 2014; 44:302-307

31. Folha de São Paulo. SP tem primeiro caso de primo "manso" da dengue. Folha de São Paulo; 2015. (Accessed 2015 Dec $7^{\text {th }}$ ). Available at http://wwwl.folha.uol.com.br/fsp/saudeciencia/220222-sp-temprimeiro-caso-de-primo-manso-da-dengue.shtml

32. Zammarchi L, Stella G, Mantella A, Bartolozzi D, Tappe D, Guntyher $\mathrm{S}$, et al. Zika virus infections imported to Italy: Clinical, immunological and virological findings, and public health implications. J Clin Virol $2015 ; 63: 32-35$

33. Vasconcelos PFC. Doença pelo vírus Zika: um novo problema emergente nas Américas? Rev Pan-amaz Saúde 2015; 6:9-10.

34. Musso D, Nhan T, Robin E, Roche C, Bierlaire D, Zisou K, et al. Potential for Zika virus transmission through blood transfusion demonstrated during an outbreak in French Polynesia, November 2013 to February 2014. Euro Surveill 2014; 19:pii:20761.

35. Ministério da Saúde. Ministério da Saúde divulga novos dados de microcefalia. Portal da Saúde; 2015. (Accessed 2015 Dec $7^{\text {th }}$ ). Available at: $\quad$ http://portalsaude.saude.gov.br/index.php/cidadao/principal/ agencia-saude/21019-ministerio-da-saude-divulga-novos-dados-demicrocefalia.

36. Lenharo M. Detecção de zika no líquido amniótico feita pela Fiocruz é inédita na ciência. Portal G1; 2015. (Accessed 2015 Dec $7^{\text {th }}$ ) Available at http://g1.globo.com/bemestar/noticia/2015/11/deteccao-de-zika-noliquido-amniotico-feita-pela-fiocruz-e-inedita-na-ciencia.html.

37. Besnard M, Lastère S, Teissier A, Cao-Lormeau VM, Musso D. Evidence of perinatal transmission of Zika virus, French Polynesia, December 2013 and February 2014. Euro Surveill 2014; 19:pii:20751.

38. Roth A, Mercier A, Lepers C, Hoy D, Duituturaga S, Benyon E, et al. Concurrent outbreaks of dengue, chikungunya and Zika virus infections - an unprecedented wave of mosquito-borne in the Pacific 2012-2014. Euro Surveill 2014; 19: pii:20929.

39. Haddow AJ, Williams MC, Woodall JP, Simpson DI, Goma LK. Twelve isolations of Zika Virus from Aedes (Stegomyia) africanus (Theobald) taken in and above a Uganda Forest. Bull World Health Organ 1964; 31:57-69.

40. Diallo D, Sall AA, Diagne CT, Faye O, Faye O, Ousmane, et al. Zika virus emergence in mosquitoes in southeastern Senegal, 2011. PLoS One 2014; 9:e109442.

41. Grard G, Caron M, Mombo IM, Nkoghe D, Ondo SM, Jiolle D, et al. Zika Virus in Gabon (Central Africa) - 2007: A new threat from Aedes albopictus? Plos Negl Trop Dis 2014; 8:e2681.
42. Boorman JP, Porterfield JS. A simple technique for infection of mosquitoes with virus: transmission of Zika virus. Trans R Soc Trop Med Hyg 1956; 50:238-242.

43. Ledermann JP, Guillaumot L, Yug L, Saweyog SC, Tided M, Machieng $\mathrm{P}$, et al. Aedes hensilli as a potential vector of Chikungunya and Zika Viruses. PLoS Negl Trop Dis 2014; 8:e3188.

44. Musso D, Roche C, Robin E, Nhan T, Teissier A, Cao-Lormeau VM. Potential sexual transmission of Zika virus. Emerg Inf Dis 2015; 21:359-361

45. Foy BD, Kobylinski KC, Foy JLC, Blivtvich BJ, Travassos da Rosa A, Haddow AD, et al. Probable non-vector-borne transmission of Zika virus, Colorado, USA. Emerg Infect Dis 2011; 17:880-882.

46. Vasconcelos PFC. Febre amarela. Rev Soc Bras Med Trop 2003; 36:275-293.

47. Gaffigan TV, Wilkerson RC, Pecor JE, Stoffer JA, Anderson T. Systematic Catalog of Culicidae. The Walter Reed Biosystematics Unit; 2015. (Accessed $2015 \mathrm{Dec} 7 \mathrm{th}$ ). Available at http://mosquitocatalog. org/default.aspx?pgID $=2$

48. Christophers R. Aedes aegypti (L.), the yellow fever mosquito: its life history, bionomics and structure. Cambridge: Cambridge University Press; 1962.

49. Rozendaal JA. Vector control. Methods for using by individuals and communities. Geneva: World Health Organization; 1997.

50. Maciel-de-Freitas R, Brock Neto R, Gonçalves JM, Codeço CT, Lourenço-de-Oliveira R. Movement of dengue vectors between the human modified environment and an urban forest in Rio de Janeiro. J Med Entomol 2006; 43:1112-1120.

51. Black WC IV, Bennett KE, Gorrochótegui-Escalante N, Barillas-Mury CV, Fernández-Salas I, Muñoz ML, et al. Flavivirus susceptibility in Aedes aegypti. Arch Med Res 2002; 33:379-388.

52. Melandri V, Guimarães AE, Komar N, Nogueira ML, Mondini A, Fernandez-Sesma A, et al. Serological detection of West Nile virus in horses and chicken from Pantanal, Brazil. Mem Inst Oswaldo Cruz 2012; 107:1073-1075.

53. Granwehr BP, Lillibridge KM, Higgs S, Mason PW, Aronson JF, Campbell GA, et al. West Nile virus: where are we now? Lancet Infect Dis 2004; 4:547-556.

54. Van der Stuiff P, Gianella A, Pirard M, Cespedes J, Lora J, Peredo C, et al. Urbanisation of yellow fever in Santa Cruz, Bolivia. Lancet 1999; 353:1558-1562.

55. Massad E, Burattini MN, Coutinho FAB, Lopez LF. Dengue and the risk of urban yellow fever reintroduction in São Paulo State, Brazil. Rev Saude Publica 2003; 37:477-484.

56. Massad E, Ma S, Burattini MN, Tun Y, Coutinho FAB, Ang LW. The risk of Chikungunya fever in a dengue-endemic area. J Travel Med 2008; 15:147-155.

57. Juliano AS, Lounibos LP. Ecology of invasive mosquitoes: effects on resident species and on human health. Ecol Letters 2005; 8:558-574.

58. Carvalho RG, Lourenço-de-Oliveira R, Braga IA. Updating the geographical distribution and frequency of Aedes albopictus in Brazil with remarks regarding its range in the Americas. Mem Inst Oswaldo Cruz 2014; 109: 787-796.

59. Pancetti FGM, Honório NA, Urbinatti PR, Lima-Camara TN. Twentyeight years of Aedes albopictus in Brazil: a rationale to maintain active entomological and epidemiological surveillance. Rev Soc Bras Med Trop 2015; 48:87-89.

60. Marques CCA, Marques GRA, Degallier N. Is Aedes albopictus only a pest mosquito or also a vector of arboviruses in Brazil? In: Travassos da Rosa APA, Vasconcelos PFC, Travassos da Rosa JFS, editors. An overview of arbovirology in Brazil and neighbouring countries. Belém: Evandro Chagas Institute; 1998. p. 248-260. 
61. Joshi V, Sharma RC, Sharma Y, Adha S, Sharma K, Singh H, et al. Importance of socioeconomic status and tree holes in distribution of Aedes mosquitoes (Diptera: Culicidae) in Jodhpur, Rajasthan, India. J Med Entomol 2006; 43:330-336.

62. Müller GA, Marcondes CB. First report of oviposition of Aedes albopictus (Skuse, 1894) (Diptera: Culicidae) through holes in bamboos in the Americas. Entomol News 2010; 121:102-103.

63. Gomes AC, Torres MAN, Gutierrez MFC, Lemos FL, Lima MLN, Martins JF, et al. Registro de Aedes albopictus em áreas epizoóticas de febre amarela das regiões Sudeste e Sul do Brasil (Diptera: Culicidae). Epidemiol Serv Saude 2008; 17:71-76.

64. Gratz NG. Critical review of the vector status of Aedes albopictus. Med Vet Entomol 2004; 18:215-227.

65. Johnson BW, Chambers TV, Crabtree MB, Filippis AMB, Vilarinhos PTR, Resende MC. Vector competence of Brazilian Aedes aegypti and Ae. albopictus for a Brazilian yellow fever isolate. Trans R Soc Trop Med Hyg 2002; 96:611-613.

66. Obara MT, Monteiro H, Paula MB, Gomes AC. Infecção natural de Haemagogus janthinomys e Haemagogus leucocelaenus pelo vírus da febre amarela no Distrito Federal, Brasil, 2007-2008. Epidemiol Serv Saude 2012; 21:457-463.

67. Cardoso JC, Almeida MAB, Santos E, Fonseca DF, Sallum MAM, Noll CA, et al. Yellow fever virus in Haemagogus leucocelaenus and Aedes serratus mosquitoes, Southern Brazil, 2008. Emerg Inf Dis 2010; 16:1918-1924.

68. Reis JG. Situação da Dengue no RS. Centro Estadual De Vigilância Em Saúde do Rio Grande do Sul; 2015. (Accessed 2015 Dec $7^{\text {th }}$ ). Available at http://www.saude.rs.gov.br/upload/1429795954_co_pia\%20de\%20 APRESENTAC_A_O\%20DENGUE\%2007gabbardo.pdf

69. Paupy C, Ollomo B, Kamgang B, Moutailler S, Rousset, D, Demanou, $\mathrm{M}$, et al. Comparative role of Aedes albopictus and Aedes aegypti in the emergence of dengue and Chikungunya in Central Africa. Vector Borne Zoonotic Dis 2010; 10:259-266.

70. Degallier N, Teixeira JMS, Soares SS, Pereira RD, Pinto SCF, Chaib AJM, et al. Aedes albopictus may not be vector of dengue virus in human epidemics in Brazil. Rev Saude Publ 2003; 37:386-387.

71. Reinert JF. Recent introductions of aedine species (Diptera: Culicidae: Aedini) into new geographic areas. Eur Mosquito Bull 2009; 27:10-17.

72. Trpis M. Breeding of Aedes aegypti and A. simpsoni under the escarpment of the Tanzanian plateau. Bull World Health Organ 1972; 47:77-82.

73. World Health Organization. Prevention and control of yellow fever in Africa. Geneva: WHO; 1985.
74. Miyagi I, Toma T, Tsukamoto M, Mogi M, Horio M, Cabrera BD, et al. A survey of the mosquito fauna in Palawan, Mindanao and North Luzon, Republic of Philippines. Mosquito Syst 1985; 17:133-146.

75. Shroyer DA. Establishment of Wyeomyia mitchellii on the island of Oahu, Hawaii. Mosquito News 1981; 41:805-806.

76. Marie J, Bossin HC. First record of Wyeomyia (Wyeomyia) mitchellii (Diptera: Culicidae) in French Polynesia. J Med Entomol 2013; 50:37-42.

77. Montarsi F, Martini S, Dal Pont M, Delai N, Ferro Milone N, Mazzucato $\mathrm{M}$, et al. Distribution and habitat characterization of the recently introduced invasive mosquito Aedes koreicus [Hulecoeteomyia koreica], a new potential vector and pest in north-eastern Italy. Parasit Vectors 2013; 6:292.

78. Schaffner F, Kaufmann C, Hegglin D, Mathis A. The invasive mosquito Aedes japonicus in Central Europe. Med Vet Entomol 2009; 23:448-451.

79. Armistead JS, Nishimura N, Arias JR, Lounibos LP. Community ecology of container mosquitoes (Diptera: Culicidae) in Virginia following invasion by Aedes japonicus. J Med Entomol 2012; 49:1318-1327.

80. Medlock JM, Hansford KM, Versteirt V, Cull B, Kampen H, Fontenille $\mathrm{D}$, et al. An entomological review of invasive mosquitoes in Europe. Bull Entomol Res 2015; 105:637-663.

81. Nasci RS, Hare SG, Willis FS. Interspecific mating between Louisiana strains of Aedes albopictus and Aedes aegypti in the field and laboratory. J Am Mosq Control Assoc 1989; 5:416-421.

82. Ribeiro JM. Can satyrs control pests and vectors? J Med Entomol $1988 ; 25: 431-440$.

83. Kampen H, Werner D. Out of the bush: the Asian bush mosquito Aedes japonicus japonicus (Theobald, 1901) (Diptera, Culicidae) becomes invasive. Parasit Vectors 2014; 7:59.

84. Richards SL, Ponnusamy L, Unnasch TR, Hassan HK, Apperson CS. Host-feeding patterns of Aedes albopictus (Diptera: Culicidae) in relation to availability of human and domestic animals in suburban landscapes of Central North Carolina. J Med Entomol 2006; 43:543-551.

85. Kek K, Hapuarachchi HC, Chung CY, Humaidi MB, Razak MA, Chiang S, et al. Feeding host range of Aedes albopictus (Diptera: Culicidae) demonstrates its opportunistic host-seeking behavior in rural Singapore. J Med Entomol 2014; 51:880-884.

86. Moreira LA, Iturbe-Ormaetxe I, Jeffery JA, Lu G, Pyke AT, Hedges LM, et al. A Wolbachia symbiont in Aedes aegypti limits infection with dengue, Chikungunya, and Plasmodium. Cell 2009; 139:1268-1278.

87. Thomé RCA, Yang HM, Esteva L. Optimal control of Aedes aegypti mosquitoes by the sterile insect technique and insecticide. Mathem Biosc 2010; 223:12-23. 